\title{
Monika Kaźmierczak* Innowacje w procesie adaptacji pracowniczej
}

Streszczenie: w artykule przedstawiono podstawowe problemy adaptacji pracowniczej, od których pomyślnego rozwiązania zależy szybkość osiągnięcia przez pracownika pełnej sprawności w wykorzystywaniu swojego potencjału. Spośród rozmaitych instrumentów i metod stosowanych w procesie adaptacji zwrócono uwagę na te, które charakteryzują się innowacyjnością. W szczególności dotyczy to wprowadzenia do tego procesu elementów grywalizacji. Rozważania zawarte w artykule zilustrowano na przykładzie procedur adaptacyjnych stosowanych w firmie z sektora branży motoryzacyjnej działającej na terenie województwa łódzkiego.

Słowa kluczowe: zarządzanie zasobami ludzkimi, adaptacja pracowników, innowacja.

\section{Wstęp}

Pierwszy dzień pracy, nowe miejsce, nieznana kultura organizacyjna, zintegrowane otoczenie, w którym jest się obcym - wszystkie te elementy występujące razem są przyczyną ogromnego stresu dla początkującego pracownika. W tym okresie nowo zatrudniony potrzebuje ogromnego wsparcia ze strony pracodawcy oraz otwartości całego zespołu, z którym będzie współpracował. Adaptacja jest jednym z najważniejszych elementów procesu zarządzania zasobami ludzkimi, a odpowiednio przeprowadzona dostarcza wymiernych korzyści obu stronom: pracownikowi i organizacji. Innowacyjne formy wdrażania pracowników do organizacji pozwalają szybko i skutecznie zdobyć lojalnego i oddanego pracodawcy pracownika poprzez przełamanie barier. Innowacje $\mathrm{w}$ adaptacji polegają na wprowadzeniu nowego pracownika w życie organizacji w sposób zupełnie dla niego nowy i zaskakujący. Takie formy, jak: luźna rozmowa, wykonywanie zabawnych zadań, podejmowanie wyzwań, przyjacielska atmosfera, sprzyjają budowaniu nieformalnych więzi oraz tworzeniu zgranych zespołów pracowniczych. Innowacyjna

* Uniwersytet Łódzki, Wydział Zarządzania, studia licencjackie. 
adaptacja jest doskonałym narzędziem przyswajania nowych obowiązków, a także stworzenia nici porozumienia $\mathrm{z}$ doświadczonymi pracownikami. Dzięki takim działaniom nowicjusz przełamuje zawstydzenie i nie boi się prosić o pomoc w każdej sytuacji. Problem podjęty w artykule wskazuje na potrzebę poszukiwania często nieszablonowych, ale skutecznych metod adaptacji pracowników. Jego celem było przedstawienie wpływu nowoczesnych metod procesu wdrożenia nowego pracownika na efektywność jego pracy, lojalność, a także jakość relacji międzyludzkich.

\section{Istota i cele adaptacji pracowniczej}

Adaptacja pracownicza jest niebywale istotnym czynnikiem prawidłowego funkcjonowania $\mathrm{w}$ organizacji zarówno $\mathrm{z}$ punktu widzenia firmy, jak i wprowadzanego do niej pracownika. Adaptacja nowej osoby wciąż stanowi jedno z najtrudniejszych zagadnień społecznych. Problem jest indywidualny, ponieważ każdy boryka się z nim osobiście. Składają się na niego czynniki psychologiczne, ekonomiczne i socjologiczne. W różnym stopniu występuje w każdej organizacji, która przyjmuje nowych pracowników.

Zdaniem Oleksyna wprowadzenie do pracy stanowi finalną część procesu kadrowego, która następuje zaraz po odpowiedniej selekcji pracowników. Jej celem jest szybka i bezinwazyjna aklimatyzacja jednostki do nowego środowiska pracy, ale również odpowiednie przygotowanie zespołu na dołączenie nowego członka [Oleksyn, 2006: 83]. Taka sytuacja sprawia kłopoty obu stronom, dlatego proces adaptacji jest ważny i trzeba się do niego dobrze przygotować. Adaptacja umożliwia szybkie zintegrowanie się z organizacją, a co za tym idzie - daje szansę na wydajne i efektywne zapoznanie pracownika z zadaniami, oczekiwaniami i uprawnieniami na danym stanowisku, metodami i środkami w celu realizacji przydzielonych poleceń. Pozwala także na zagkębienie się w kulturę organizacyjną, wartości, zapoznanie się ze strategią, misją, wizją, historią firmy oraz stosunki interpersonalne panujące $w$ grupach nieformalnych. Nowy pracownik może zdobyć samodzielność, pewność siebie, zyskać biegłość w działaniu oraz opanować praktyczną część swojej roli organizacyjnej. Efektywny proces adaptacji pomaga pracownikowi nabrać wprawy i stać się pełnowartościowym kapitałem firmy.

Pracownik, który wchodzi do firmy, ofiarowuje jej swoje umiejętności, zaangażowanie i kwalifikacje, jednak w zamian za to spodziewa się rekompensaty materialnej i niematerialnej [March, Simon, 1964: 37], m.in. w postaci programu adaptacji pracowniczej. Według Żwirek wdro- 
żenie do pracy, które pozwala osiągnąć zamierzone cele, nie tylko wpłynie na pozytywne postrzeganie organizacji przez pracownika (a co za tym idzie - zwiększenie motywacji), ale przede wszystkim pozwoli nowicjuszowi osiągnąć pełną efektywność, na poziomie doświadczonych pracowników, w znacznie krótszym czasie, co wiąże się z wymiernymi korzyściami dla organizacji. Stopniowe, systematyczne wprowadzanie nowych pracowników w poszczególne obszary działalności może zwiększyć zyski z zatrudnienia $\mathrm{w}$ firmie. To, że pracownik będzie dobrze znał relacje wewnętrzne $\mathrm{w}$ firmie i że pozna zewnętrzne relacje $\mathrm{z}$ klientem, sprawi, że zaangażowanie $\mathrm{w}$ świadczenie usług na wysokim poziomie znacznie wzrośnie. Wpłynie też pozytywnie na realizację kluczowych zadań na jego stanowisku [Żwirek, 2015].

Bańka uważa, że nowo przyjęty pracownik powinien być wprowadzony do organizacji przez przełożonego. Do zadań tego ostatniego należy poinformowanie nowicjusza o strukturze, historii firmy, celach, zadaniach oraz przysługujących mu prawach. Ważne jest, by przełożony naświetlił, jak wyglądają relacje między współpracownikami oraz jaka panuje atmosfera $\mathrm{w}$ zespołach. Ta wiedza na temat firmy w znacznym stopniu zmniejszy stres i napięcie związane z aklimatyzacją w pracy. Ada-ptacja przeprowadzana $\mathrm{w}$ taki sposób podnosi morale oraz wzmacnia poczucie wartości pracownika. Ostatecznie niepokój związany z nowymi obowiązkami oraz nowymi ludźmi zaciera się. Dlatego niezwykle istotne jest opracowanie konkretnego programu wprowadzenia do pracy przez komórkę kadrową [Bańska, 2002: 21].

Przydzielenie opiekuna i wpływ grupy koleżeńskiej powodują, że pracownik szybciej dostosowuje się do nowej roli i obowiązków, ma większą wydajność, a wśród jego mentorów i współpracowników rośnie poziom zadowolenia z wykonywanych zadań. Dobra współpraca między członkami zespołu przynosi rezultaty w postaci realizacji celów organizacyjnych (wzrost konkurencyjności firmy na rynku) oraz indywidualnych, do których dąży sam pracownik.

Pomoc, którą nowicjusz otrzymuje od organizacji, ma przełożenie na jego lojalność wobec pracodawcy. To najlepszy moment na zyskanie sympatii pracownika. Jednak sama istota wprowadzenia do pracy polega głównie na przekazie informacji dotyczących miejsca pracy i zakresu obowiązków, a także na stopniowym poznawaniu współpracowników, kultury organizacyjnej i zwyczajów panujących w firmie.

Korczyńska twierdzi, że odpowiednia adaptacja nowego pracownika wynika przede wszystkim z troski o organizację. Firma poświęciła bardzo dużo czasu oraz poniosła koszty rekrutacji i selekcji, więc nie może sobie pozwolić na potknięcie podczas przystosowania pracownika do pracy na danym stanowisku. Dlatego na etapie wprowadzania do pracy 
najważniejsze jest przyjazne nastawienie oraz chęć realnej pomocy w pierwszych dniach po zatrudnieniu. W tym okresie informacje muszą być przekazywane prosto i klarownie, najlepiej w formie broszury lub vademecum pracownika, do którego zawsze można wrócić, kiedy zajdzie taka potrzeba. Jednak organizacja nie powinna polegać wyłącznie na słowie drukowanym. Sukces procesu adaptacyjnego zależy głównie od bezpośredniego kontaktu $\mathrm{z}$ opiekunem lub przełożonym oraz informacji zwrotnej, która z tego wynika [Korczyńska, 2002: 54].

Zdaniem Davisa dzięki procesowi adaptacji nowy pracownik powinien w jak najkrótszym czasie stać się wydajny i w pełni zaangażowany w pracę. Jeśli zostaną mu przekazane jedynie informacje o firmie, to wydajność i produktywność, których życzyłby sobie pracodawca, nie zostaną osiągnięte. Jeśli zaś zbudujemy proces adaptacyjny z myślą o rozwijaniu motywacji, umiejętności liderskich oraz indywidualnej odpowiedzialności jasnej wizji celu, będzie on naturalnym bodźcem do lojalności wobec firmy oraz elastyczności w podejściu do obowiązków na stanowisku pracy, pozwoli również na odkrycie nowych talentów [Davis, 2003: 29]. Odpowiednio przekazane wiadomości mają ogromy wpływ na jakość wykonywania zadań na nowym stanowisku pracy oraz efektywność realizacji celów organizacji i zatrudnionego.

Znalezienie nowego pracownika, proces rekrutacji i selekcji bywają pracochłonne, trudne i kosztowne. Pracodawcy zużywają na to mnóstwo energii i pieniędzy. $\mathrm{Z}$ powodu wysiłku wkładanego $\mathrm{w}$ dwa pierwsze etapy często zapominają, co dzieje się z pracownikiem po zatrudnieniu $-\mathrm{w}$ jego pierwszych, najtrudniejszych dniach pracy. Na etapie adaptacji można wiele zyskać, ale również stracić. Zatrudnienie nowych pracowników nie powinno się wiązać $\mathrm{z}$ wrzucaniem na głęboką wodę, ale uwzględniać realną pomoc, umożliwiającą wdrożenie i przyśpieszającą uzyskanie samodzielności przez pracownika. Jeśli zaś pozostawi się pracownika samemu sobie i powierzy mu zadania, które w jego opinii są trudne i skomplikowane, wyrobi on sobie przekonanie, że wszystko może zawdzięczać wyłącznie sobie. Organizacja straci tylko czas i środki finansowe na rekrutację, a pracownik - zawodowe poczucie własnej wartości i dobrą opinię w oczach pracodawcy.

\section{Instrumenty i metody adaptacji}

Instrumenty adaptacji pracowniczej mają na celu wsparcie nowo zatrudnionych pracowników w trakcie adaptacji. Przygotowując programy asymilacyjne, organizacja sprytnie wdraża pracowników i pomaga dostosować się im do specyfiki firmy oraz kultury organizacyjnej. Zdaniem 
Syper-Jędrzejak wiele przedsiębiorstw sięga po znane i sprawdzone narzędzia wspierania pracownika w tym trudnym dla niego czasie zawodowym. Rozwiązania te są bardzo korzystne, ponieważ informacje o organizacji znajdują się w jednym miejscu, pracownik nie musi poszukiwać ich na własną rękę u różnych, często niezbyt dobrze poinformowanych źródeł [Syper-Jędrzejak, 2013]. Według Adamskiej-Chudzińskiej odpowiednie przystosowanie zawodowe jest podstawowym warunkiem sprawnego działania i efektywnego funkcjonowania pracownika w organizacji [Adamska-Chudzińska, 2012: 83]. Aby tego dokonać, należy odpowiednio dobrać i zastosować narzędzia adaptacyjne, takie jak:

- materiały informacyjne;

- mentoring (opiekun);

- coaching;

- broszury, katalogi, prezentacje, filmiki, e-maile powitalne i wiele innych.

Wprowadzanie w życie metod przystosowawczych przynosi znacznie lepsze efekty, a także pozwala pracownikom uzyskiwać informacje i rozwijać umiejętności zawodowe w odpowiednim dla nich czasie [Davis, 2003: 46].

Najpopularniejszymi kanałami dotarcia do nowo zatrudnionego pracownika są:

- broszura o organizacji,

- katalog wewnętrzny lub publikacje,

- prezentacje multimedialne,

- filmiki lub maile powitalne,

- zapoznanie z zespołem współpracowników.

System informacyjno-komunikacyjny jest kluczowy w procesie adaptacyjnym, dzięki niemu adaptacja może odbywać się grupowo bądź indywidualnie. To znacznie skraca okres przystosowania do pracy oraz dokładnie zapoznaje pracownika z funkcjonowaniem całej organizacji.

Podstawowe informacje, jakie powinny się znaleźć w kanale informacyjnym dla nowych pracowników, to: misja, wizja, strategia organizacji, zasady wynagradzania, motywacje materialne i niematerialne, organizacja czasu pracy, zapoznanie z kluczowymi partnerami, klientami lub kontrahentami. Zdaniem Oleksyna dysponowanie taką wiedzą i ciągła jej aktualizacja mają ogromny wpływ na nawiązanie współpracy wewnątrz firmy i poza nią [Oleksyn, 2006: 83]. Sygnalizowane są w ten sposób wartości organizacji i oczekiwane normy zachowań. Dla pracowników ważne jest ponadto jasne określenie zasad zabezpieczeń socjalnych, ale również obowiązków, zakresu zadań i odpowiedzialności, jaka się z tym wiąże. Mile widziana dla nowicjusza jest wyraźnie nakreślona 
kultura organizacyjna, która wytycza oraz pozwala zrozumieć wiele zachowań współpracowników. To bardzo pomaga w nawiązaniu kontaktów, a także przyspiesza efektywną pracę w grupie.

Pierwszy etap realizacji ww. opisanego procesu opiera się na broszurach, filmikach, prezentacjach i tym podobnych elementach systemu informacyjnego, drugi - na regulaminach organizacyjnych oraz wewnętrznych wytycznych pracy. Następna faza polega na zapoznaniu się z narzędziami i sposobami wykorzystywanymi do instruktażu stanowiskowego, jak: karty zakresów obowiązków, szkolenia i realizacji zadań, instrukcje dotyczące prowadzenia projektów czy też wyposażenia stanowisk pracy. Kolejną metodą jest mentoring. W organizacjach używa się tego instrumentu m.in. do rozwoju pracowników. Mentoring to partnerska relacja między mistrzem (opiekunem) a uczniem (nowo zatrudnionym pracownikiem). Pracodawca przydziela nowej osobie mentora, zwanego również przewodnikiem, opiekunem. Zdaniem Karwela mentoring zorientowany jest głównie na odkrywanie i rozwijanie potencjału ucznia, opiera się na partnerstwie, współpracy, inspiracji i stymulacji do działań. Dzięki odpowiednim zabiegom uczeń poznaje zarówno organizację, jak i siebie, co zapewnia rozwój świadomości i satysfakcję, a także - co najważniejsze - kształtuje tożsamość organizacyjną [Karwel, 2007: 237]. Mentoring obejmuje również doradztwo, ewaluację oraz pomoc w programowaniu sukcesu pracownika. To narzędzie powinno być przystosowane przede wszystkim do oczekiwań i potrzeb pracownika.

Mentorem może być odpowiednio przygotowana lub wykształcona w tym kierunku osoba z zewnątrz. Najczęściej tę odpowiedzialną rolę powierza się bezpośrednim przełożonym lub doświadczonym pracownikom organizacji, którzy wyróżniają się mocno rozwiniętymi kompetencjami społecznymi, profesjonalizmem, autorytetem oraz z reguły dhugoletnim stażem. Dobór utalentowanego przewodnika jest kluczowym elementem w procesie mentoringu. Nie powinniśmy jednak zrażać się brakiem nieskazitelnej i bezbłędnej osoby w firmie, której można powierzyć nowicjusza pod opiekę. Najistotniejsze jest to, aby uczniowie chcieli i mogli uczyć się od takiej osoby. Jednym z głównych założeń tego procesu jest po prostu pomoc ofiarowywana nowym pracownikom. Zadanie mentora polega na umiejętnym wprowadzeniu nowo zatrudnionego w szeregi organizacji oraz kształtowaniu umiejętności przez treningi lub doświadczenie. Przy pomocy opiekuna uczeń powinien przede wszystkim zapoznać się z obowiązkami i zadaniami charakteryzującymi dane stanowisko pracy. Ponieważ mentor zna zasady panujące w firmie, może przekazać je o wiele bardziej efektywnie, niż uczyniłyby to same broszury bądź filmiki instruktażowe. Dzięki tak zdeklarowanej pomocy pracownik z łatwością przebrnie przez perypetie w początkowym (i nie tylko) okresie 
pracy. Należy jednak pamiętać, że opiekun niekoniecznie musi być psychologiem i że nie będzie rozwiązywał wszystkich skomplikowanych problemów rodzinnych lub życiowych, natomiast zajmuje się pracownikiem od momentu wejścia do organizacji i tym samym rozpoczęcia procesu adaptacji. Mentor nie zagłębia się i nie analizuje tego, co działo się w przeszłości. Proces mentoringu ma formę opieki nad uczniem w różnych stadiach jego rozwoju i kariery w organizacji. Doskonali umiejętności menedżerskie poprzez wykorzystywanie doświadczenia współpracowników o wyższych kompetencjach i pozycji w hierarchii firmy.

Zdaniem Babczyńskiego doświadczony pracownik, mentor, opiekun, bezpośredni przełożony - w zależności od tego, kogo organizacja wyznaczy do pełnienia istotnej funkcji przewodnika po firmie - zajmuje się głównie:

- wzajemnym poznawaniem i określaniem celów;

- ułatwianiem kontaktów interpersonalnych;

- identyfikacją słabych i mocnych stron, a także szans i zagrożeń dla rozwoju ucznia;

- zachęcaniem do własnej inicjatywy oraz samodzielnego nieszablonowego myślenia;

- konsekwentną realizacją i weryfikacją obranej ścieżki kariery;

- regularną obiektywną oceną wyników;

- feedbackiem - ciągłą informacją zwrotną [Babczyński, 2011].

Coaching oznacza dosłownie ,trening”, jednak to thumaczenie nie oddaje właściwego sensu tej metody. Zdaniem Sidor-Rządkowskiej coaching to uporządkowany proces oparty na współpracy, zmierzający do rozwiązania problemów, a także dbałość o samopoczucie uczestników [Sidor-Rządkowska, 2012: 14-15]. Coaching obejmuje rozmaite działania podejmowane przez wyszkoloną kadrę służące indywidualnemu rozwojowi pracowników, przyśpieszające osiąganie ustalonych celów oraz polepszające efekty pracy. Starr uważa, że coaching w najprostszym ujęciu to nic innego jak seria rozmów dwóch osób, z których jedna jest trenerem i dąży do ukształtowania konwersacji przynoszącej korzyści drugiej osobie [Starr, 2005: 10]. Dzięki wdrożeniu coachingu w procesie adaptacji nowy pracownik od samego początku uczy się ustalać jasne, konkretne, realne i określone w czasie cele. Potrafi również optymalizować swoje działania, podejmować trafniejsze decyzje oraz opiera się na swoich naturalnych umiejętnościach.

Rolą trenera jest zaawansowane wykorzystywanie umiejętności słuchania, pytania i wysnuwania refleksji w celu prowadzenia rozmów tak, aby każda z nich była bogatym i pouczającym doświadczeniem dla podopiecznego [Starr, 2005: 19]. Coach to osoba mająca wymagany zestaw umiejętności i kompetencji przydatnych w procesie adaptacji. Potrafi 
czerpać z doświadczenia życiowego oraz technik i narzędzi pomocnych w odkrywaniu nowej drogi do celów prywatnych i zawodowych. Dla pracownika jest swego rodzaju drogowskazem i motywatorem, ponieważ nieustannie stymuluje do działania. Natomiast priorytety, do których będą razem dążyć, ustala pracownik. Dzięki temu świadomie dokonuje pozytywnych zmian w swoim życiu, a coach pozwala mu dać z siebie to, co najlepsze.

Profity płynące $\mathrm{z}$ wprowadzenia tej metody do firmy są miarodajne i dla pracownika, i dla organizacji. Oto najważniejsze z nich:

- stymuluje do działania;

- pomaga osiągać cele zawodowe i prywatne;

- uczy podejmowania świadomych decyzji;

- otwiera i pobudzał potencjał drzemiący w pracowniku;

- daje poczucie satysfakcji z wykonywanej pracy;

- poprawia relacje pracownik-pracownik, przełożony-pracownik;

- wzmacnia indywidualne zaangażowanie $\mathrm{i}$ wyniki w pracy;

- kreuje pozytywną atmosferę i kulturę organizacyjną;

- stopniowo pokazuje granice między życiem prywatnym a zawodowym;

- wzmacnia najsłabsze ogniwa organizacji;

- doskonali pracę zespołową;

- rozwija kluczowe umiejętności na danym stanowisku pracy;

- motywuje;

- zwiększa integrację z organizacją;

- wyłania liderów w zespołach;

- podnosi konkurencyjność firmy na rynku;

- uświadamia potrzeby ciągłego uczenia się;

- doskonali i odkrywa kompetencje;

- uczy pewności siebie;

- pokazuje, że porażka to nic złego [Rzycka, 2010: 34].

W dzisiejszych czasach, trudnych i konkurencyjnych, organizacje nastawione na sukces powinny posługiwać się metodami i narzędziami ukierunkowanymi na rozwój, poszukiwanie kreatywnych pracowników mających umiejętności szybkiego przyswajania informacji i korzystania z nich oraz umiejętności adaptacyjne w nowych sytuacjach. Należy im w tym jednak pomóc.

Innowacyjnym podejściem jest wprowadzanie elementów grywalizacji do procesu adaptacji. Pierwsze dni pracy nowicjusza zmieniają się w grę naszpikowaną mnóstwem informacji dotyczących firmy, a on sam jest jej głównym bohaterem. Wykorzystuje zebrane informacje do zapoznania się z otoczeniem, zbiera punkty i pokonuje kolejne poziomy. Dzięki tej metodzie pracownik szybko nabiera umiejętności potrzebnych 
do wykonywania obowiązków, rozwiązuje zadania związane z docelową pracą, uczy się podejmować decyzje i wykorzystywać nabytą wiedzę. Jest to ciekawy element, który cieszy się dużym uznaniem nawet wśród menedżerów wysokiego szczebla [Kordecka-Myślińska, 2013].

Uatrakcyjnieniem procesu przedstawiania nowego pracownika mogą być różnorodne konkursy. Dobrym przykładem jest losowanie towarzysza, z którym nowicjusz zje obiad, czyli lunch roulette. Zabawa polega na tym, że wdrażana osoba wyciąga los z imieniem i nazwiskiem przypadkowego pracownika firmy z całej, często rozbudowanej struktury organizacyjnej. Jego zadaniem jest opowiedzieć jak najwięcej o swoim miejscu pracy. To innowacyjna metoda, dzięki której można poznać różne punkty widzenia osób $\mathrm{z}$ różnych działów, które często nie mają przyjemności się ze sobą zetknąć. Wspólny posiłek pozwala porozmawiać na neutralnym gruncie, zapoznać się z nowymi ludźmi, tworzyć kontakty i pozytywne wspomnienia, a co najważniejsze, wprowadzić w stan odprężenia [Banasiak, Widak, 2015].

Ostatnią nowatorską i mało znaną praktyką jest wdrażanie procesu za pomocą tzw. pokoju adaptacji. $\mathrm{W}$ tym miejscu pracownik zanurza się w przestrzeni, w której spotyka się jedynie z „ORGANIZACJĄ”. Znajdują się tam przedmioty kojarzone $\mathrm{z}$ firmą, gadżety związane z jej tradycją, długopisy i kalendarze $z$ logo, na ścianach widnieją hasła zachęcające do pracy w tej firmie, zdjęcia pracowników wraz z ich imionami, prezentacja multimedialna przedstawiająca historię oraz przypominająca przełomowe dla marki momenty. Ta metoda wydaje się kontrowersyjna, natomiast cieszy się sporym uznaniem wśród nowych pracowników. Pokój zaaranżowany z myślą o nowych pracownikach wpływa pozytywnie na sposób postrzegania organizacji. Pokój adaptacji wykorzystywany jest sporadycznie w polskich warunkach, ale budzi duże poczucie przynależności i z pewnością na długo zapada w pamięć gościa [Kordecka-Myślińska, 2013].

Dobrze zrealizowany proces onboardingu to mechanizm, który ma uczynić z nowych pracowników niezależnych, pewnych siebie i produktywnych członków przedsiębiorstw. W zwykłym wdrażaniu istnieją trzy główne obszary wiedzy, które powinny być wykorzystane: 1) wiedza techniczna i operacyjna; 2) wiedza o firmie; 3) wiedza z zakresu rozwoju osobistego na danym stanowisku [Gil-Baranek].

$\mathrm{W}$ połączeniu z innowacją programy adaptacyjne dostarczają wielu pozytywnych wrażeń, zachęcają do nawiązywania kontaktów, uczą podejmowania szybkich i trafnych decyzji, pozwalają bezstresowo włączyć nowego człowieka w zabiegane życie organizacji i poznać kanały prze- 
kazu informacji. Ponadto odrywają od rutyny, pozyskują lojalnych i wydajnych pracowników, dzięki nim pracownik zapamiętuje organizację jako przyjaznego i kreatywnego pracodawcę.

\section{Innowacyjna adaptacja pracowników w badanej firmie}

Poniżej przedstawiono proces adaptacji pracowników w doświadczonej firmie działającej w branży motoryzacyjnej na terenie województwa łódzkiego. Zakres usług obejmuje sprzedaż i montaż części do samochodów amerykańskich marek. Przedsiębiorstwo istnieje na rynku od 2005 r. Od początku wyróżnia się ogromną pasją i zaangażowaniem, stawia na bezpieczeństwo i wysoką jakość oferowanych usług. Organizacja bierze udział w zlotach samochodowych na terenie całej Polski, promując w ten sposób własną markę i wizję. Otwartość na innowacje oraz zmieniające się otoczenie, a także wysoka specjalizacja działalności pozwoliły nawiązać współpracę z rzeszą stałych klientów indywidualnych oraz firmami reprezentującymi znane amerykańskie marki z sektora motoryzacyjnego. Firma daje się poznać nie tylko jako doskonały sprzedawca oferowanych usług, ale również jako przyjazny pracodawca. Nie jest zbyt duża, dzięki czemu pracownicy mają ze sobą bardzo dobry kontakt. W okresie letnim właściciel często organizuje grille i spotkania integracyjne dla wszystkich pracowników i ich rodzin.

Wybrano ją jako przedmiot badań, ponieważ utożsamia się także $\mathrm{z}$ trendami panującymi w obszarze zarządzania zasobami ludzkimi. Jednym z nich jest innowacyjna i swobodna forma adaptacji pracowniczej, która tworzy poczucie przynależności do „pozytywnie zakręconego” zespołu. Działalność i pasję do samochodów amerykańskich często opisują hasła ,jeepnięci” i ,variaci”.

Zarząd firmy wdrożył innowacyjny proces szybkiej adaptacji i zapoznania nowego pracownika z zespołem, trwający 5 dni. Poniżej przedstawiono jego opis z wyszczególnieniem działań w każdym z tych dni.

Pierwszego dnia pracy przyjęty pracownik witany jest przez właściciela firmy, który prowadzi z nim luźną rozmowę na codzienne tematy, takie jak: zainteresowania, motoryzacja, sport, dzieci i pasje. Głównym celami takiego postępowania są m.in.:

- budowanie wizerunku właściciela jako osoby troskliwej i zaangażowanej w działanie zespołu tworzącego jego przedsiębiorstwo;

- poznanie pracownika, jego postawy, opinii, charakteru;

- stworzenia bazy do budowania zaangażowania nowej osoby;

- budowanie poczucia pewności osoby w nowym otoczeniu. 
Dla lepszej identyfikacji z firmą podczas rozmowy właściciel wykorzystuje gadżety reklamowe, np. używa firmowego kubka lub filiżanki, długopisu/pióra, notesu, częstuje cukierkami owiniętymi w firmowe opakowanie. Po rozmowie do gabinetu zapraszany są wszyscy pracownicy w celu poznania nowego członka zespołu. W tym momencie nowemu pracownikowi zostaje przydzielony opiekun. Jego zadaniami przez pierwszy tydzień pracy będą m.in.:

- zapoznanie pracownika z firmą, jej polityką, strukturą, zasadami, historią, kulturą organizacyjną;

- odpowiadanie na wszelkie pytania lub wątpliwości;

- przydzielanie i objaśnianie zadań;

- prowadzenie procesu integracyjnego z zespołem firmy;

- końcowa ocena pracownika pod kątem weryfikacji jego możliwości adaptacyjnych do otoczenia i przygotowania do pracy.

Pierwszego dnia opiekun prowadzi z nowym pracownikiem luźną, nieformalną rozmowę i pokazuje mu jego stanowisko, udziela wszelkich informacji na temat przedsiębiorstwa. Następnie wskazuje miejsce pracy, przy którym oprócz standardowych narzędzi pracy znajdują się także gadżety firmowe, w tym cukierki. Są też kredki i biała kartka, a pierwszym zadaniem pracownika jest narysowanie, jak widzi siebie i w jakim punkcie zawodowym za 20 lat. Pracownik otrzymuje także broszurę informacyjną z misją i wizją firmy, wzbogaconą w materiały wewnętrzne, takie jak zdjęcia $\mathrm{z}$ imprez integracyjnych, warsztatów i szkoleń.

Po ogólnym wprowadzeniu następuje część merytoryczna, na którą składają się omówienie zakresu obowiązków i przeszkolenie z BHP. Jeśli nowy pracownik poczuje zmęczenie, opiekun może skorzystać z zajęć rekreacyjnych, takich jak tenis stołowy, trampolina itp. Po skończonym treningu kontynuowany jest proces wdrażania do czasu zakończenia godzin pracy.

Drugi dzień również rozpoczyna się od indywidualnego spotkania z właścicielem firmy, który podczas rozmowy stara się uzyskać opinię pracownika o pierwszym dniu pracy, jego wrażeniach i przydzielonym opiekunie. Rozmowa ma charakter nieformalny i towarzyski, wprawdzie odbywa się w gabinecie, jednak przy kawie i słodkim poczęstunku. Interesującym zjawiskiem podczas tej rozmowy jest przypisywanie do kontaktu telefonicznego zindywidualizowanych sygnałów dźwiękowych. Właściciel firmy pyta nowego pracownika o jego ulubiony utwór, a następnie przypisuje go do kontaktu. To samo robi pracownik firmy, przypisując ulubioną muzykę przełożonego do jego numeru telefonu. Na koniec spotkania właściciel zaprasza osobiście nowego pracownika na najbliższe 
przedsięwzięcie integracyjne firmy, którym jest najczęściej zlot samochodów amerykańskich.

W dalszej części dnia proces integracyjny prowadzi opiekun, który udziela dalszych wskazówek i instrukcji stanowiskowych. Częścią szkolenia są także spotkania indywidualne z innymi pracownikami. Opiekun stara się, aby częściowo odbywały się one bez jego udziału. Tworzy w ten sposób możliwość rozmowy bez skrępowania jego osobą. Wszystkie obowiązki tego dnia pracownik wykonuje pod okiem opiekuna.

$\mathrm{W}$ trzecim dniu właściciel firmy nie bierze już udziału w procesie integracji, a pracownik rozpoczyna pracę przy biurku. W ramach nawiązywania relacji koleżeńskich na jego biurku czekają już cukierki oraz kawa przygotowane przez pozostałych członków zespołu. Właściciel ogranicza się do wysłania drogą mailową wiadomości z niezobowiązującymi, komicznymi filmami oraz zdjęciami z imprez firmowych.

Podobnie jak drugiego dnia wszystkie obowiązki pracownik wykonuje pod okiem opiekuna. W międzyczasie prowadzony jest dalszy proces zapoznawania i integracji z pozostałymi członkami zespołu pracowniczego.

Czwartego dnia, tak jak w dniu poprzednim, na nowego pracownika czekają na biurku kawa i cukierki firmowe. Dodatkowymi elementami są karta umożliwiająca korzystanie z obiektów sportowych (multisport) i model samochodu do sklejania - bez instrukcji.

Pierwszym zadaniem w tym dniu jest złożenie modelu na czas, jednak nie dłuższy niż 15 minut. Obowiązki wykonywane są nadal w obecności opiekuna, który w ciągu dnia organizuje jedną dłuższą przerwę - pracownik może wybrać jedną $\mathrm{z}$ ofert sportowych na terenie organizacji (trampolina, ping-pong, spacer) lub dodatkową przechadzkę po warsztacie czy rozmowę. Pracownik losuje osobę, z którą spędzi ten czas.

Piątego dnia na biurku pracownika znajduje się kartka z zadaniami do wykonania:

- przygotowanie porannej kawy dla wszystkich pracowników,

- zjedzenie cytryny z uśmiechem,

- rzucenie cukierkiem we wskazaną osobę,

- zrobienie zeza,

- udawanie traktora,

- opowiedzenie dowcipu.

Po wykonaniu wszystkich punków na pracownika czeka nagroda - selfie ze wszystkimi pracownikami, które następnie trafia na centralne miejsce tablicy informacyjnej. Nowy pracownik wybiera również stację radiową, której wszyscy słuchają przez cały dzień. Piątek jest ostatnim dniem pracy z opiekunem, który powtarza z pracownikiem całą przekazaną wiedzę, procedury i zasady obowiązujące w przedsiębiorstwie. 
W drugiej części dnia pracownik zostaje poproszony na rozmowę z właścicielem, której celem jest uzyskanie feedbacku po procesie integracyjnym. Przełożony w trakcie luźnej rozmowy pyta o pracowników, opiekuna, ocenę integracji oraz zasad i procedur panujących w firmie). Rozmowę kończy przypomnienie o zbliżającej się imprezie integracyjnej/szkoleniu. Pracownik zwalniany jest do domu godzinę wcześniej.

\section{Zakończenie}

Wykorzystywanie innowacyjnych form powitania pomaga wzbudzić w nowo zatrudnionych pracownikach poczucie lojalności wobec pracodawcy oraz skrócić dystans w relacjach międzyludzkich. Innowacje $\mathrm{w}$ adaptacji polegają na wprowadzeniu nowego pracownika do organizacji w sposób niestandardowy, np. poprzez wykonywanie zabawnych zadań, wyzwań, którym towarzyszy swobodna rozmowa. Ma to na celu stworzenie spójnych i efektywnych zespołów. Przyswajanie nowych obowiązków w przyjaznej i zabawnej atmosferze jest o wiele bardziej efektywne, buduje nieformalne więzi i tworzy nić sympatii między pracownikiem a pracodawcą. Dokładnie takie działania zostały wdrożone w badanej firmie, w której nowicjusze dostają niezbędne wskazówki do pracy, a także zapoznają się z kulturą organizacji, jej historią, obowiązującymi zasadami i procedurami, a co najważniejsze - zakresem obowiązków podczas tygodniowej, oryginalnej sesji adaptacyjnej.

Najistotniejszą konsekwencją takiego postępowania jest utożsamienie się nowych pracowników z firmą, co wzmacnia zaangażowanie oraz emocjonalne przywiązanie do organizacji i zespołu. Dzięki tak przeprowadzonemu procesowi adaptacji firma może cieszyć się zgraną drużyną zmotywowanych do pracy ludzi, którzy wiedzą, po co się tutaj znaleźli. Ponadto nowi pracownicy doskonale znają zakres swoich obowiązków, cele, do których dążą, oraz zwyczaje panujące $\mathrm{w}$ danym miejscu pracy. Z punktu widzenia pracownika korzyści wynikające $\mathrm{z}$ innowacyjnego wdrożenia są równie istotne jak te dla organizacji. Nowa osoba nie czuje się wyobcowana wśród zaaklimatyzowanych już pracowników, jest zauważana, co daje jej poczucie akceptacji w nowym środowisku. Już na samym początku staje się częścią organizacji i chętnie współpracuje, ponieważ wie, że tworzy coś absolutnie unikatowego i potrzebnego dla prawidłowego funkcjonowania firmy. Dzięki wprowadzanym do procesu adaptacji innowacjom ma okazję przeżyć ciekawą przygodę - i to pozytywne wrażenie pozostanie, nawet jeśli zakończy pracy w danej organizacji. 
Przeprowadzone badania własne pokazują, że dzięki innowacyjnemu procesowi wdrożenia do pracy nowy pracownik już na wstępie jest bardzo zadowolony z zatrudnienia. Pozwala to również budować satysfakcjonujące relacje na poziomie organizacja-pracownik oraz zespół-pracownik. Sięganie po niestandardowe rozwiązania $\mathrm{w}$ adaptacji może być zatem bardzo korzystne, i to nie tylko w początkowym okresie pracy, ale też w perspektywie długoterminowej. Jest to efekt pozytywnego pierwszego wrażenia, jakie wywarła firma na nowym pracowniku.

\section{BIBLIOGRAFIA}

Adamska-Chudzińska M. (2012), Uwarunkowania sprawności zawodowej człowieka w organizacji, Wydawnictwo Uniwersytetu Ekonomicznego w Krakowie, Kraków.

Armstrong M. (2005), Zarządzanie zasobami ludzkimi, Oficyna Ekonomiczna, Kraków.

Babczyński B. (2011), Nowoczesne formy rozwoju pracownika, http://wuplodz.praca. gov.pl/documents/58203/842291/Nowoczesne\%20formy\%20rozwoju\%20pracownika. pdf/b4c4a834-bb9e-4831-aa81-ff8257fb2d47?t=1406796129000 (dostęp: 19.01.2016).

Banasiak A., Widak N. (2015), Onboarding 2.0-czyli dlaczego zwykte ,,dzień dobry” nie wystarcza?, http://www.kadry.abc.com.pl/czytaj/-/artykul/onboarding-2-0--czyli-dlaczego-zwykle-dzien-dobry-nie-wystarcza (dostęp: 15.03.2016).

Bańka W. (2002), Zarządzanie personelem w średniej i małej firmie, Adam Marszałek, Toruń.

Bora P., Marek E., Ankieta, https://mfiles.pl/pl/index.php/Ankieta (dostęp: 10.05.2016).

Davis P. (2003), Adaptacja zawodowa, Petit, Warszawa.

Dobiesz-Żarczyńska A. (2008), Adaptacja nowego pracownika do pracy w przedsiębiorstwie, Oficyna a Wolters Kluwer business, Kraków.

Drucker P., Stawni o HR, http://sedlak.pl/Cytaty.html?strona=3 (dostęp: 18.12.2015).

Frankowski, P., Skubiak, B. (2012), Innowacyjność $w$ teorii ekonomii i praktyce gospodarczej, „Studia i Prace Wydziału Nauk Ekonomicznych i Zarządzania”, nr 30.

Geodecki T., Mamica Ł. (2014), Polityka innowacyjna, Polskie Wydawnictwo Ekonomiczne, Warszawa.

Gil-Baranek K., Wdrażanie nowych pracowników, http://nf.pl/manager/wdrazanie-nowych-pracownikow,15164,39 (dostęp: 16.03.2016).

Janowska Z. (2002), Zarządzanie zasobami ludzkimi, Polskie Wydawnictwo Ekonomiczne, Warszawa.

Jasieński M. (2014), Innowatyka - nowy horyzont. Innowacyjność naukowców przedsiębiorców, menedżerów i urzędników, Centrum Innowatyki, Wyższa Szkoła Biznesu - National-Louis University, Nowy Sącz.

Karwel S. (2007), Organizacje komercyjne i niekomercyjne wobec wzmożonej konkurencji oraz wzrastających wymagań konsumentów, Drukarnia Millenium, Nowy Sącz.

Komisja Europejska (2008), Podręcznik Oslo: Zasady gromadzenia i interpretacji danych dotyczacych innowacji, http://www.rpo.lodzkie.pl/images/konkurs_2.3.1_cop _28122015/Podrecznik_OSLO.pdf(dostęp: 10.03.2016).

Korczyńska B. (2002), Zarządzanie zasobami ludzkimi, Wyższa Szkoła Umiejętności Pedagogicznych i Zarządzania, Ryki. 
Kordecka-Myślińska A. (2013), http://hrstandard.pl/2013/10/04/rzecz-o-adaptacjiswiezo-zatrudnionych/ (dostęp: 15.03.2016).

Kozioł-Nadolna K. (2012), Modele zarzadzania innowacjami w XXI wieku, [w:] Mikuła B. (red.), Historia i powstanie nauk o zarzadzaniu, Wydawnictwo Uniwersytetu Ekonomicznego w Krakowie, Kraków.

Machnik-Słomka J. (2014), Innowacje społeczne w teorii i w praktyce, Polskie Wydawnictwo Ekonomiczne, Warszawa.

March J.G., Simon H.A. (1964), Teoria organizacji, PWN, Warszawa.

Olejniczuk-Merta A. (2014), Innowacje społeczne. Od idei do upowszechnienia efektu, Instytut Badań Rynku Konsumpcji i Koniunktur, Warszawa.

Oleksyn T. (2006), Zarządzanie zasobami ludzkimi w organizacji, Oficyna a Wolters Kluwer business, Warszawa.

Ostrowska A. (2005), Innowacje przełomowe, http://www.pi.gov.pl/PARP/chapter _86197.asp?soid=CBAC934E3B15454296D20B44785F8764 (dostęp: 29.02.2016).

Pawlik A. (2009), Internet jako przyklad aktywności innowacyjnej przedsiębiorstw, „Studia i Materiały. Miscellanea Oeconomicae", nr 1, http://miscellanea.ujk.edu.pl/ data/Oferta/Pliki/82_Art_Pawlik_A.pdf(dostęp: 29.02.2016).

Penc J. (2006), Sztuka skutecznego zarządzania, Oficyna Ekonomiczna, Kraków.

Pomykalski A. (2009), Innowacyjność organizacji, Wydawnictwo Naukowe Wyższej Szkoły Kupieckiej, Łódź.

Rzycka O. (2010), Menedżer coachem. Jak rozmawiać, by osiagnać rezultaty, Wolters Kluwer, Warszawa.

Sidor-Rządkowska M. (2010), Zarządzanie personelem w matej firmie, Wolters Kluwer, Warszawa.

Sidor-Rządkowska M. (2012), Profesjonalny coaching. Zasady i dylematy etyczne w pracy coacha, Oficyna a Wolters Kluwer business, Warszawa.

Starr J. (2005), Coaching. Procesy, zasady i umiejętności, Polskie Wydawnictwo Ekonomiczne, Warszawa.

Syper-Jędrzejak M. (2013), Dobre praktyki w zakresie adaptacji pracowników na przykładzie wybranych firm z regionu tódzkiego, „Zarządzanie i Finanse”, nr 1, http://zif.wzr.pl/pim/2013_1_4_33.pdf(dostęp: 16.01.2016).

Szukalski S.M. (2009), Innowacyjność organizacji, Wydawnictwo Naukowe Wyższej Szkoły Kupieckiej, Łódź.

Trompenaars F. (2010), Kultura innowacji. Kreatywność pracowników a sukces firmy, Wolters Kluwer, Warszawa.

Wojciechowski A., Teoria innowacji, http://www.wmarr.olsztyn.pl/newsletter/files/file/ Artyku\%C5\%82\%20I\%20-\%20Teoria\%20innowacji.doc. (dostęp: 29.02.2016).

Zaleśna A. (2013), Innowacyjność w małych firmach - propozycja modelu dojrzewania do zarzadzania innowacjami, „Zeszyty Naukowe”, t. 3, http://www.wsp.pl/ file/1191_883674528.pdf (dostęp: 15.02.2016).

Żołnierski A. (2005), Innowacyjność polskich mikroprzedsiębiorstw, Polska Agencja Rozwoju Przedsiębiorczości, Warszawa.

Żwirek K., Adaptacja zawodowa, www.abk.wsps.pl/images/poradnik-pliki/adaptacjazawodowa (dostęp: 10.11.2015). 


\section{INNOVATIONS IN THE PROCESS \\ OF EMPLOYEE ADAPTATION}

\section{SUMMARY}

The article presents the basic problems of employee adaptation, whose successful course determines the employee's ability to achieve full efficiency in their potential. Among the various instruments and methods used in the adaptation process, attention has been paid to those that are characterized by innovation. In particular, this refers to the introduction of elements of gamification into this process. The considerations contained in the article are illustrated by an example of adaptation procedures applied in a company from the automotive sector operating in the Lodz region.

Keywords: human resource management, employee adaptation, innovation. 